\title{
Platelet-Derived Vesicles in Hypertension: New Target for Risk Stratification?
}

\author{
Alexander E Berezin*1 and Alexander A Berezin ${ }^{2}$ \\ ${ }^{1}$ Senior Consultant of Therapeutic Unit, Internal Medicine Department, Ukraine \\ ${ }^{2}$ Internal Medicine Department, Medical Academy of Postgraduate Education, Ukraine
}

*Corresponding author: Alexander E Berezin, Professor, Senior Consultant of Therapeutic Unit, Internal Medicine Department, State Medical University of Zaporozhye, 26, Mayakovsky av., Zaporozhye, Ukraine

\begin{abstract}
ARTICLE INFO
Received: 慧 April 30, 2019

Published: May 09, 2019

Citation: Alexander E Berezin, Alexander A Berezin. Platelet-Derived Vesicles in Hypertension: New Target for Risk Stratification?. Biomed J Sci \& Tech Res 17(5)-2019. BJSTR. MS.ID.003072.
\end{abstract}

Abbreviations: EVs: Extracellular Vesicles; MVs: Micro Vesicles; PS: Phosphatidylserine; MAP: Mitogen-Activated Protein; VEGFR: Vascular Endothelial Growth Factor Receptor
ABSTRACT

Extracellular vesicles (EVs) are involved in the pathogenesis of CV diseases through several biological mechanisms that support microvascular inflammation, arterial stiffness, vascular calcification, atherosclerotic plaque shaping and rupture, endothelial dysfunction, hypercoagulation and thrombosis, cardiac remodelling, and kidney dysfunction. Platelet activation, which is associated with secretion of EV, is common for arterial hypertension. The aim of the mini review is to discuss the role of platelet-derived micro vesicles as predictive biomarker in hypertension. It has found that elevated levels of EVs and altered signature of platelet-derived vesicles are biomarkers of endothelial dysfunction, accelerating atherosclerosis, pro-coagulation state, and poor clinical outcomes. The diagnostic and predictive roles of this biomarker in hypertensive patients require to be investigated in large clinical trials in the future.

Keywords: Platelet-Derived Vesicles; Hypertension; Cardiovascular Risk; Endothelial Dysfunction; Prediction; Prognosis

\section{Introduction}

Extracellular vesicles (EVs) are defined as small sized (range of diameter is approximately $150 \mathrm{~nm}$ and less) exosomes that deliver biologically active molecules (peptides, RNAs, active molecules, growth factors, hormones, enzymes) from mother cells to recipient cells through binding, fusion or endocytosis appearing to be a core element in cell-to-cell cooperation [1,2]. They are involved in the pathogenesis of $\mathrm{CV}$ diseases through several biological mechanisms that support microvascular inflammation, arterial stiffness, vascular calcification, atherosclerotic plaque shaping and rupture, endothelial dysfunction, hypercoagulation and thrombosis, cardiac remodelling, and kidney dysfunction [3,4]. Additionally, via intracellular signaling cascades EVs play a pivotal role in tissue reparation, angiogenesis, and neovascularization $[5,6]$.

In fact, EVs mediate autocrine and paracrine signals that are enabled to reconstructing the homeostatic micro-environment in heart and vessels [7]. EVs are released a wide spectrum of cells, including endothelial cells, cardiomyocytes, red blood cells, mononuclear / macrophages, as well as platelets. EVs, which are produced by endothelial precursors and mature endothelial cells, as well as mononuclears, are under investigations for long time respectively and there is evidence regarding predictive capability of altered circulating number of EVs in established CV disease including hypertension [8,9]. On contrary, the exact role of plateletderived micro vesicles in pathogenesis of hypertension remains to be not fully discovered. The aim of the mini review is to discuss the role of platelet-derived micro vesicles as predictive biomarker in hypertension.

\section{Extracellular Vesicles: Definition}

Extracellular vesicles (EVs) are defined as small sized $(<1000$ $\mathrm{nm}$ ) cell membranous originated structures that secreted by various cells (platelets, red and white blood cells, endothelial cells, precursors / stem cells, cardiomyocytes, and even tumor cells) into 
human fluids and contained wide range of proteins, hormones, signalling molecules, lipids, mRNA, miRNA, and others $[10,11]$. There are at least two distinct subpopulations of EVs (exosomes and micro vesicles [MVs]), which distinguish each other in size, compounds, immune phenotypes and wide range of formation modes. Exosomes are sufficiently smaller to MVs (size averages are $30-120 \mathrm{~nm}$ and $40-1000 \mathrm{~nm}$ respectively) and are shaped by the endocytosis of multivesicular bodies and are shed from cells by exocytosis. On contrary, MVs are defined as membranebound vesicles, which are released from the plasma membrane. Additionally, surface-specific antigens, which are presented for both populations of EVs, are different, but they overlap between exosomes and MVs that does not allow differencing both populations of the particles. Physiologically, EVs are a cargo for molecule transfer, auto / paracrine signalling, cell-to-cell cooperation, playing a pivotal role in immune response, vascular integrity, cellular senescence, tissue reparation and development, angiogenesis and neovascularization $[12,13]$. In fact, EVs are able to mediate the exchange of appropriate information between various cells. EVs were found witness and biomarkers of several diseases, such as $\mathrm{CV}$, autoimmune, infective, metabolic, renal, rheumatic, neurological, ocular diseases and malignancy [14-17]

\section{Platelet-Derived Vesicles}

The population of the platelet-derived vesicles is the largest in other types of EVs in the circulation. Indeed, the majority of the blood-borne EVs are thought to originate from the megakaryocytes, i.e. either from circulating platelets or directly from the platelet precursor cells, which reside in the bone marrow. Although coagulation, thrombosis, vascular senescence and permeability are most common and well-established biological function of platelet-derived vesicles, the role of them in $\mathrm{CV}$ diseases has not exhausted a crucial impact on hemostasis. Elevated levels of platelet-derived vesicles were determined in patients with acute coronary syndrome, myocardial infarction, as well as heparininduced thrombocytopenia, thrombotic complications, hemolytic uremic syndrome, while developing of abdominal obesity, diabetes mellitus, antiphospholipid syndrome, and sepsis was not associated with increased circulating level of platelet-derived vesicles [18]. Probably, this evidence might relate to the mechanisms regarding release of MPs from platelets. It has suggested that in various cases circulating platelets are likely to adhere to leukocytes or endothelial cells at the activation site and that the circulating platelet-derived
MPs are likely to be a residue of activated platelets [19].

It has been found that upon activation, blood platelets are able to release two types of EVs, i.e. micro particles and exosomes. Platelet-derived micro particles are characterized by average of size of 70-100 $\mathrm{nm}$ and the phosphatidylserine (PS) presentation at their surface, which mediates their capabilities in coagulation and thrombosis [20]. On contrary, platelet-derived exosomes are characterized by their small size $(<80 \mathrm{~nm})$ and the presence of CD63 antigen, which is known as the tetraspanin that belongs to the transmembrane 4 superfamily $[19,20]$. CD63 plays a pivotal role in the role in the activation of cellular signalling cascades that trigger AkT, FAK-related non-kinase polypeptide / protein tyrosine kinase-2 (PTK-2) and mitogen-activated protein (MAP) kinases, attenuates an adhesion of circulating monocytes / macrophages onto endothelial cells through the regulation of P-selectin (CD62) trafficking, as well as promotes vascular endothelial growth factor receptor (VEGFR) signalling and internationalization [21]. All these factors are embedded into cell-to-cell cooperation and cell interactions with the extracellular matrix. Moreover, EVs expressing Ms4a2/FceRI on the surface are able to be triggers for degranulation of circulating cell in response to other stimuli [22]. Additionally, some EVs may express CD41 (Integrin alpha-IIb) on their surface, which in a complex with CD61 may be a receptor for thrombospondin, fibronectin, vitronectin, fibrinogen, and von Willebrand factor playing a crucial role in blood coagulation [22,23].

The populations of the platelet-derived EVs may distinguish each other in not just their size and immune phenotype, but yet they could have different in density (utilized as sucrose density gradient in ultracentrifugation), proteomic and lipidomic profiles [24] Labeling of platelet-derived EVs is reported in the Table 1. Although there is difficulties in identification of distinction between both two types of EVs (micro particles and exosomes) in cargo potency, immune heterogeneity and size averaging of EV populations allows identifying them using several methods for their isolation and quantification, including conventional and cryo-enhanced electron microscopy, immuno-gold labelling, laser-scanning confocal microscopy, nanoparticle tracking analysis and flow cytometry $[25,26]$ However, lack of generally accepted methods as a standard for determination, isolation and quantification of platelet-derived EVs, sufficiently limits our efforts in understanding their biological role in the pathogenesis of several states and diseases $[27,28]$ 
Table 1: Labelling of platelet-derived EVs with surface CD markers.

\begin{tabular}{|c|c|c|c|c|c|}
\hline CD Marker & Alternative Name & Prominent Feature & Cell Labelling & Expression & Significance \\
\hline CD9 & $\begin{array}{c}\text { Tetraspanin (Tspan } \\
\text { 29) }\end{array}$ & $\begin{array}{l}\text { Key regulator of intracellular } \\
\text { signalling, proliferation, } \\
\text { activation, survival, migration, } \\
\text { invasion, cell adhesion, and } \\
\text { diapedesis }\end{array}$ & $\begin{array}{c}\text { Platelets, B cells, CD4+ T } \\
\text { cells, CD8+ T cells, natural } \\
\text { killer cells, granulocytes, } \\
\text { monocytes and } \\
\text { macrophages, and immature } \\
\text { and mature dendritic cells }\end{array}$ & Low & $\begin{array}{l}\text { None-specific lympho / } \\
\text { hematopoietic marker }\end{array}$ \\
\hline CD23 & Fc epsilon RII (FceRII) & $\begin{array}{l}\text { Interaction with many ligands } \\
\text { (IgE, CD21, MHC class II, } \\
\text { integrins), exhibiting pleiotropic } \\
\text { cytokine-like activities, sustaining } \\
\text { the growth of activated B-cells, } \\
\text { differentiation of myeloid } \\
\text { precursors, thymocytes and } \\
\text { bone marrow CD4+ T cells, } \\
\text { degranulation of platelets }\end{array}$ & $\begin{array}{c}\text { Platelets, T and } \\
\text { B lymphocytes, } \\
\text { polymorphonuclear } \\
\text { leucocytes, monocytes, } \\
\text { follicular dendritic cells, } \\
\text { intestinal epithelial cells, } \\
\text { bone marrow stromal cells }\end{array}$ & Low & $\begin{array}{l}\text { None-specific } \\
\text { lymphohematopoietic } \\
\text { marker, diagnostic } \\
\text { marker for neoplastic } \\
\text { and autoimmune } \\
\text { inflammatory disease }\end{array}$ \\
\hline CD31 & $\begin{array}{l}\text { PECAM-1, GP IIa, hec7 } \\
\text { antigen, EndoCAM }\end{array}$ & $\begin{array}{l}\text { Key inhibitory receptor in } \\
\text { circulating platelets and } \\
\text { leukocytes, major endothelial } \\
\text { mechanosensor, modulator } \\
\text { of vascular permeability, and } \\
\text { leukocyte trafficking, and cell-to- } \\
\text { cell cooperation, core player in in } \\
\text { thrombosis, inflammation and the } \\
\text { immune response }\end{array}$ & $\begin{array}{c}\text { Platelets, leucocytes, } \\
\text { monocytes / mononuclears, } \\
\text { endothelial cells, EPCs }\end{array}$ & High & $\begin{array}{l}\text { A maker of endothelial } \\
\text { integrity, vascular } \\
\text { permeability, platelet } \\
\text { degranulation, } \\
\text { endothelialopathies } \\
\text { in tumor angiogenesis } \\
\text { and the growth and } \\
\text { development of } \\
\text { hemangiomas }\end{array}$ \\
\hline CD36 & GP-IV, Scarb3 & $\begin{array}{l}\text { Recognition of thrombospondine, } \\
\text { fatty acids, collagen, adhesion of } \\
\text { platelets }\end{array}$ & $\begin{array}{l}\text { Monocytes, macrophages, } \\
\text { platelets, adipose cells, } \\
\text { endothelial cells, PECs, } \\
\text { epithelial cells }\end{array}$ & High & Platelet collagen receptor \\
\hline CD41 & $\begin{array}{l}\alpha I I b \text { integrin, platelet } \\
\text { GPIIb }\end{array}$ & $\begin{array}{c}\text { Key regulator of growth and } \\
\text { differentiation }\end{array}$ & $\begin{array}{l}\text { Hematopoetic progenitors } \\
\text { in embrio, specific to the } \\
\text { megakaryocytic / platelet } \\
\text { lineage }\end{array}$ & Moderate & $\begin{array}{c}\text { Markers of all progenitors } \\
\text { (megakaryocytic, } \\
\text { granulomacrophagic, } \\
\text { erythroid and pluripotent } \\
\text { cells) }\end{array}$ \\
\hline $\operatorname{CD} 42(a, b, c)$ & $\begin{array}{l}\text { Integrin subunit } \alpha I I b \text {, } \\
\text { GPIIb }\end{array}$ & $\begin{array}{l}\text { Regulator of platelet activation } \\
\text { and adhesion }\end{array}$ & Platelets & High & $\begin{array}{l}\text { Marker of platelet } \\
\text { aggregation }\end{array}$ \\
\hline CD49f & $\begin{array}{l}\text { GPIc, integrin } \alpha 6- \\
\text { chain, ITGA6, ITGA6B, } \\
\text { VLA } 6 \text { alpha Subunit }\end{array}$ & $\begin{array}{l}\text { Regulator of embryogenesis, } \\
\text { cell adhesion and cell migration } \\
\text { through T-cell receptor/CD3 } \\
\text { complex }\end{array}$ & $\begin{array}{l}\text { T cells, endothelial cells, } \\
\text { epithelial cell, macrophages, } \\
\text { monocytes; platelets and } \\
\text { stem cell }\end{array}$ & High & $\begin{array}{l}\text { Marker of blood cell } \\
\text { adhesion and T-cell } \\
\text { proliferation }\end{array}$ \\
\hline CD51 & $\begin{array}{l}\text { Integrin subunit alpha } \\
\text { V, vitronectin receptor }\end{array}$ & $\begin{array}{l}\text { Trigger of cell adhesion and } \\
\text { signal transduction, regulator } \\
\text { of angiogenesis and cancer } \\
\text { progression }\end{array}$ & $\begin{array}{l}\text { T cells, endothelial cells, } \\
\text { platelets }\end{array}$ & & \\
\hline CD61 & $\begin{array}{l}\text { GP3A, integrin subunit } \\
\text { beta } 3\end{array}$ & $\begin{array}{l}\text { Regulator of cell adhesion and } \\
\text { cell-surface mediated signalling }\end{array}$ & $\begin{array}{c}\text { Endothelial cells, } \\
\text { Macrophage, platelets }\end{array}$ & High & $\begin{array}{l}\text { Marker of human } \\
\text { megakaryocytic cell } \\
\text { lineages }\end{array}$ \\
\hline CD84 & $\begin{array}{l}\text { Cell surface antigen } \\
\text { MAX.3, Ly-9B, } \\
\text { SLAMF-5 }\end{array}$ & $\begin{array}{l}\text { Regulator of signalling and } \\
\text { adhesion in lymphocytic cells and } \\
\text { other cells }\end{array}$ & $\begin{array}{l}\text { Thymus and spleen cells, } \\
\text { cells of megakaryocytic } \\
\text { lineages }\end{array}$ & Moderate & $\begin{array}{l}\text { Marker of adhesion } \\
\text { interactions between } \\
\text { T lymphocytes and } \\
\text { accessory cells, platelets }\end{array}$ \\
\hline CD92 & $\begin{array}{l}\text { Choline Transporter } \\
\text { like Protein } 1\end{array}$ & $\begin{array}{c}\text { Regulator of cell growth and } \\
\text { differentiation }\end{array}$ & $\begin{array}{l}\text { Subset of bone marrow } \\
\text { stromal cells, cells of } \\
\text { osteogenic, megakaryocytic } \\
\text { and adipogenic lineages }\end{array}$ & High & $\begin{array}{l}\text { Marker of human bone } \\
\text { marrow stromal cells, and } \\
\text { cells of megakaryocytic } \\
\text { and adipogenic lineages }\end{array}$ \\
\hline CD110 & $\begin{array}{c}\text { MPL proto-oncogene, } \\
\text { TPO-R, }\end{array}$ & Regulator of heamopoesis & $\begin{array}{l}\text { Subset of stem cells and } \\
\text { cells of megakaryocytic } \\
\text { lineage as well as platelets }\end{array}$ & High & $\begin{array}{c}\text { Marker of megakaryocytic } \\
\text { lineage }\end{array}$ \\
\hline CD147 & BSG, EMMPRIN & $\begin{array}{c}\text { Trigger of cell proliferation } \\
\text { associated with the TGF- } \beta / \text { Smad } 4 \\
\text { signalling pathway, cell adhesion } \\
\text { and T-cell activation }\end{array}$ & $\begin{array}{l}\text { Endothelial cell, epithelial } \\
\text { cells, lymphocytes, } \\
\text { mononuclears, platelets }\end{array}$ & Low & $\begin{array}{l}\text { Marker of cell growth, } \\
\text { adhesion, and } \\
\text { proliferation, malignancy, } \\
\text { angiogenesis, vascular } \\
\text { permeability }\end{array}$ \\
\hline
\end{tabular}




\begin{tabular}{|c|c|c|c|c|c|}
\hline CD151 & $\begin{array}{l}\text { GP27, membrane } \\
\text { glycoprotein SFA-1, } \\
\text { platelet-endothelia-l } \\
\text { tetraspan antigen-3 }\end{array}$ & $\begin{array}{c}\text { Regulator of the VCAM-1 activity } \\
\text { during lymphocyte and platelet } \\
\text { recruitment }\end{array}$ & $\begin{array}{c}\text { Endothelial cells, platelets, } \\
\text { T-cells }\end{array}$ & High & $\begin{array}{c}\text { Marker of fibrosis, } \\
\text { vascular inflammation } \\
\text { and remodelling, } \\
\text { cancinogenesis, vascular } \\
\text { permeability, endothelial } \\
\text { dysfunction }\end{array}$ \\
\hline CD226 & $\begin{array}{c}\text { DNAM1, PTA1, TLiSA1, } \\
\text { DNAX }\end{array}$ & $\begin{array}{c}\text { An adhesion molecule involved } \\
\text { in NK and T cell-mediated } \\
\text { cytotoxicity }\end{array}$ & $\begin{array}{l}\text { T cells, NK cells, platelets, } \\
\text { mononuclears }\end{array}$ & Low & $\begin{array}{c}\text { Triggering cytotoxicity } \\
\text { and cytokine secretion by } \\
\text { T and NK cells }\end{array}$ \\
\hline GARP & - & $\begin{array}{c}\text { A key regulator of network } \\
\text { between Tregs and its targets }\end{array}$ & $\begin{array}{l}\text { Activated Tregs, mature } \\
\text { peripheral naive CD } 4+\mathrm{T} \\
\text { cells, platelets }\end{array}$ & Low & $\begin{array}{l}\text { Marker of activated Tregs } \\
\text { and degradated platelets }\end{array}$ \\
\hline LAP & - & $\begin{array}{c}\text { Phagosome maturation, } \\
\text { stabilization of the cargo to } \\
\text { prolong antigen presentation on } \\
\text { MHC, recruiting LC3 molecules to } \\
\text { phagosome membranes class II } \\
\text { molecules }\end{array}$ & $\begin{array}{l}\text { Macrophages, dendritic cells } \\
\text { and platelets }\end{array}$ & Low & $\begin{array}{l}\text { A marker of catabolic } \\
\text { process involved during } \\
\text { exogenous antigen } \\
\text { processing, recognition } \\
\text { of apoptotic, necrotic, or } \\
\text { entotic cells, degradation } \\
\text { of platelets }\end{array}$ \\
\hline
\end{tabular}

Abbreviations: MHC: Major Histocompatibility Complex; GP: Glycoprotein; PECAM-1: Platelet/Endothelial Cell Adhesion Molecule 1; EPCs: Endothelial Progenitor Cells; NK: Nature Killer; TPO-R: Thrombopoietin Receptor; BSG: Basigin; EMMPRIN: Extracellular Matrix Metalloproteinase Inducer; TGF- $\beta$ : Transforming Growth Factor-Beta; SLAMF-5: Signalling Lymphocytic Activation Molecule 5; LAPL LC3-Associated Phagocytosis; GARP: Glycoprotein A Repetitions Predominant.

\section{Platelet-Derived Vesicles in CV Disease}

There is large body of evidence regarding pivotal role of platelet-derived vesicles in the pathogenesis of CV diseases [2931]. In a result of several triggers, such as ischemia, hypoxia, anemia, inflammation, shear stress, blood turbulence, platelets are activated, aggregated, then they changed them contain enriching phospholipids and GPs, prepare for vesiculation via shaping spaced architectonic and exocytosis and release vesicles into circulation. Regulation platelet vesiculation is mediated via platelet $\mathrm{Ca}$ $(2+)$-ATPases by cyclic AMP through the phosphorylation of the Rap1 protein. Platelet-derived vesicles exhibit haemostatic properties, mediated aggregation of blood cells including whole platelets, promote coagulation, stabilize the vasculature and maintain endothelial cell barrier integrity [32]. Therefore, platelet-derived vesicles may demonstrate pro-atherogenic, pro-inflammatory, and immunomodulatory, even anticoagulant activity depending on triggers that induce their releasing and the expression of their surface certain molecules [33-35]. For instance, phospholipidenriched platelet-derived vesicles that express Annexin V possess as pro-atherogenic and pro-coagulant particles [36].

On contrary Annexin V-negative vesicles were found rather anticoagulant than pro-coagulant particles. Therefore, platelets contain S100A8/A9 in membrane-enclosed vesicles and transfer it to target cells including endothelial cells and their precursors [37]. Probably S100A8/A9-rich platelet-derived vesicles can play a pivotal role in developing endothelial dysfunction upon manifestation of CV disease. Additionally, platelet-derived vesicles deliver oxidized lipids, P-selectin / P-selectin glycoprotein ligand 1 (PSGL-1), CD40 ligand (CD154) and induce B-cell synthesis and secretion of antigen-specific immunoglobulin $\mathrm{G}$ and potentiate the adaptive immune response through CD4+ cells [38-40] Although restored endothelial cell junctions and vascular integrity after thrombin releasing, the balance between promoting coagulation and mitigating endothelial dysfunction and vascular permeability has being turn to the side of potentiation of platelet activation status and pro-coagulant activity [41]. This effect appears to be harmful for majority patients with established CV diseases including asymptomatic atherosclerosis, acute coronary syndrome / myocardial infarction, hypertension, hypertensive crisis, heart failure, peripheral artery disease.

\section{Platelet-Derived Vesicles in Hypertension}

Platelet activation is common for arterial hypertension and it is associated with an increase in platelet membrane P-selectin expression and a circulating number of platelet-derived vesicles enriched phosphatidylserine, which indicates pro-coagulant activity [30]. It is been postulated that activation status of platelets in patients with uncontrolled arterial hypertension is predominantly a result of elevated shear force, low-grade systemic inflammation and increased sympathetic activity [31]. Yet, there is evidence that preeclampsia / eclampsia negatively impacts on the cerebral circulation and that this effect is associated with activated platelets and platelet-derived vesicles [32]. Moreover, placental and maternal platelet-derived EVs participate in critical signaling mechanism for feto-placental development and impairment in releasing and contents of vesicles in biological fluids depending on their origin is considered in the context of the initiation and progression of the pathogenesis of preeclampsia / eclampsia [33]. In fact, non-pregnant women with the risk factors of preeclampsia / eclampsia (overweight / obesity, diabetes mellitus, rheumatic disease, systemic vasculitis, dyslipidemia, anemia) as well as individuals with arterial hypertension were identified to have elevated levels of circulating platelet-derived EVs [42-44]. 
It has been suggesting that circulating platelet-derived EVs can induce vascular dysfunction, and through immune modulation they mediate thrombotic potency of plasma and remodeling of vasculature. This mechanism appears to be common for arterial hypertension and preeclampsia, although initial triggers for both can be distinguished (i.e., shear stress and sympathetic activity for hypertension and hypoxia/ischemia, damage of placenta villi for preeclampsia). Despite these differences, final result of platelet activation and releasing of platelet-derived vesicles remain similar and it is considered an endothelial dysfunction, vascular remodeling and pro-coagulation state, which affect target organ damage and contribute to poor clinical outcomes. Moreover, elevated levels of EVs and altered signature of platelet-derived vesicles have been recognised having a discriminative potency to predict heart failure developing in patients with CV risk factors [45,46]. Renal denervation that was able to sufficiently reduce sympathetic activity in patients with resistant hypertension led to a reduction of platelet activation, monocyte-platelet aggregates and a tendency to lowering circulating number of activated platelets in close relation to declined levels of several inflammatory markers, such as tumor necrosis factor-alpha, interleukin-1beta, interleukin-12, and monocyte chemoattractant protein-1 $[31,47]$.

Although there is strong interrelation between endothelial dysfunction in hypertension and spontaneous generation of platelet-derived vesicles, whether tight control for blood pressure will correspond to a significant decrease of platelet aggregation and reducing number of circulating pro-coagulant platelet-derived vesicles is not fully understood [48]. However, diminishing of pro-coagulant activity of circulating platelet-derived vesicles can be achieved during effective antihypertensive therapy $[47,49]$. It has been noted that a wide range of antihypertensive drugs, such as calcium channel blockers, angiotensin-II receptor antagonists, angiotensin-converting enzyme inhibitors, are able to hamper the process of micro vesiculation and thereby to reduce a circulating number of platelet-derived vesicles [49-51]. Taken into consideration the role of the vesicles in the pathogenesis of hypertension a variable ability of several antihypertensive drugs to modify shaping and releasing of the particles onto circulations is showed to have promising and require more investigations in the future.

\section{Conclusion}

Elevated levels of platelet-derived vesicles are found in a wide range of thrombophilia-related condition and CV disorders including hypertension. Platelet-derived vesicles are biomarker of endothelial dysfunction and pro-coagulative activity, which can be discussed a predictor of CV complication, such as atherothrombotic events (stroke, myocardial infarction), heart failure and kidney insufficiency. The diagnostic and predictive roles of this biomarker in hypertensive patients require to be investigated in large clinical trials in the future.

\section{References}

1. Shanmuganathan M, Vughs J, Noseda M, Emanueli C (2018) Exosomes: Basic Biology and Technological Advancements Suggesting Their Potential as Ischemic Heart Disease Therapeutics. Front Physiol 9: 1159.

2. Berezin A, Zulli A, Kerrigan S, Petrovic D, Kruzliak P (2015) Predictive role of circulating endothelial-derived microparticles in cardiovascular diseases. Clin Biochem 48(9): 562-568.

3. Nawaz M, Shah N, Zanetti BR, Maugeri M, Silvestre RN, et al. (2018) Extracellular Vesicles and Matrix Remodeling Enzymes: The Emerging Roles in Extracellular Matrix Remodeling, Progression of Diseases and Tissue Repair. Cells 7(10): E167.

4. La Marca V, Fierabracci A (2017) Insights into the Diagnostic Potential of Extracellular Vesicles and Their miRNA Signature from Liquid Biopsy as Early Biomarkers of Diabetic Micro/Macrovascular Complications. Int J Mol Sci 18(9): E1974.

5. Berezin AE, Kremzer AA, Berezina TA, Martovitskaya YV (2015) Pattern of circulating microparticles in chronic heart failure patients with metabolic syndrome: Relevance to neurohumoral and inflammatory activation. BBA Clin 4: 69-75.

6. Caporali A, Martello A, Miscianinov V, Maselli D, Vono R, et al. (2017) Contribution of pericyte paracrine regulation of the endothelium to angiogenesis. Pharmacol Ther 171: 56-64.

7. De Toro J, Herschlik L, Waldner C, Mongini C (2015) Emerging roles of exosomes in normal and pathological conditions: new insights for diagnosis and therapeutic applications. Front Immunol 6: 203.

8. Berezin AE (2017) Microparticles in Chronic Heart Failure. Adv Clin Chem 81: 1-41.

9. Berezin AE, Kremzer AA, Cammarota G, Zulli A, Petrovic D, et al. (2016) Circulating endothelial-derived apoptotic microparticles and insulin resistance in non-diabetic patients with chronic heart failure. Clin Chem Lab Med 54(7): 1259-1267.

10. Chen BY, Sung CW, Chen C, Cheng CM, Lin DP, et al. (2019) Advances in exosomes technology. Clin Chim Acta 493: 14-19.

11. Juan T, Fürthauer M (2018) Biogenesis and function of ESCRT-dependent extracellular vesicles. Semin Cell Dev Biol 74: 66-77.

12. Hervera A, Santos CX, De Virgiliis F, Shah AM, Di Giovanni S (2019) Paracrine Mechanisms of Redox Signalling for Postmitotic Cell and Tissue Regeneration. Trends in Cell Biol.

13. Mobarak H, Heidarpour M, Lolicato F, Nouri M, Rahbarghazi R, et al. (2019) Physiological impact of extracellular vesicles on female reproductive system; highlights to possible restorative effects on female age-related fertility. Biofactors.

14. Navarro A, Molins L, Marrades RM, Moises J, Viñolas N, et al. (2019) Exosome Analysis in Tumor-Draining Pulmonary Vein Identifies NSCLC Patients with Higher Risk of Relapse after Curative Surgery. Cancers (Basel) 11(2): E249.

15. Aslan C, Maralbashi S, Salari F, Kahroba H, Sigaroodi F, etal. (2019) Tumorderived exosomes: Implication in angiogenesis and antiangiogenesis cancer therapy. J Cell Physiol.

16. Yang L, Zhu J, Zhang C, Wang J, Yue F, et al. (2019) Stem cell-derived extracellular vesicles for myocardial infarction: a meta-analysis of controlled animal studies. Aging (Albany NY) 11(4): 1129-1150.

17. Bei Y, Das S, Rodosthenous RS, Holvoet P, Vanhaverbeke M, et al. (2017) Extracellular Vesicles in Cardiovascular Theranostics. Theranostics 7(17): 4168-4182.

18. Kenari AN, Kastaniegaard K, Greening DW, Shambrook M, Stensballe A, et al. (2019) Exosome-mimetic nanovesicles contain distinct proteome and post-translational modified protein cargo, in comparison to exosomes. Proteomics 19(8): e1800161. 
19. Vagner T, Chin A, Mariscal J, Bannykh S, Engman D, et al. (2019) Protein composition reflects extracellular vesicle heterogeneity. Proteomics 19(8): e1800167.

20. Aatonen M, Valkonen S, Böing A, Yuana Y, Nieuwland R, et al. (2017) Isolation of Platelet-Derived Extracellular Vesicles. Methods Mol Biol 1545: 177-188.

21. Hedley BD, Llewellyn Smith N, Lang S, Hsia CC, MacNamara N, et al. (2015) Combined accurate platelet enumeration and reticulated platelet determination by flow cytometry. Cytometry B Clin Cytom 88(5): 330337.

22. Bennett JS (1990) The molecular biology of platelet membrane proteins. Semin Hematol 27: 186-204.

23. Clemetson KJ, Clemetson JM (2008) Platelet GPIb complex as a target for anti-thrombotic drug development. Thromb Haemost 99(3): 473-479.

24. Chevillet JR, Kang Q, Ruf IK, Briggs HA, Vojtech LN, et al. (2014) Quantitative and stoichiometric analysis of the microRNA content of exosomes. Proc Natl Acad Sci U S A 111(41): 14888-14893.

25. van der Pol E, Boing AN, Harrison P, Sturk A, Nieuwland R (2012) Classification, Functions, and Clinical Relevance of Extracellular Vesicles. Pharmacological Reviews 64(3): 676-705.

26. Liu C, Zhao J, Tian F, Chang J, Zhang W, et al. (2019) $\lambda$-DNA and Aptamer Mediated Sorting and Analysis of Extracellular Vesicles. J Am Chem Soc 141(9): 3817-3821.

27. Nolan JP, Jones JC (2017) Detection of platelet vesicles by flow cytometry. Platelets 28(3): 256-262.

28. Lacroix R, Robert S, Poncelet P, Kasthuri R, Key N, et al. (2010) Standardization of platelet-derived microparticle enumeration by flow cytometry with calibrated beads: results of the International Society on Thrombosis and Haemostasis SSC Collaborative workshop. Journal of Thrombosis and Haemostasis 8(11): 2571-2574.

29. Tao SC, Guo SC, Zhang CQ (2017) Platelet-derived Extracellular Vesicles: An Emerging Therapeutic Approach. Int J Biol Sci 13(7): 828-834.

30. Zaldivia MTK, Hering D, Marusic P, Sata Y, Lee R, et al. (2019) Successful Renal Denervation Decreases the Platelet Activation Status in Hypertensive Patients. Cardiovasc Res.

31. Zaldivia MT, Rivera J, Hering D, Marusic P, Sata Y, et al. (2017) Renal Denervation Reduces Monocyte Activation and Monocyte-Platelet Aggregate Formation: An Anti-Inflammatory Effect Relevant for Cardiovascular Risk. Hypertension 69(2): 323-331.

32. Barnes JN, Harvey RE, Miller KB, Jayachandran M, Malterer KR, et al. (2018) Cerebrovascular Reactivity and Vascular Activation in Postmenopausal Women with Histories of Preeclampsia. Hypertension 71(1): 110-117.

33. Van Wijk MJ, Van Bavel E, Sturk A, Nieuwland R (2003) Microparticles in cardiovascular diseases. Cardiovasc Res 59(2): 277-287.

34. Yano Y, Kambayashi J, Shiba E, Sakon M, Oiki E, et al. (1994) The role of protein phosphorylation and cytoskeletal reorganization in microparticle formation from the platelet plasma membrane. Biochem J 299(1): 303-308.

35. Gemmel CH, Sefton MV, Yeo E (1993) Platelet-derived microparticle formation involves glycoprotein IIb-IIIa. Inhibition by RGDS and a
Glanzmann's thrombasthenia defect. J Biol Chem 268(20): 1458614589.

36. Cauwenberghs S, Feijge MA, Harper AG, Sage SO, Curvers J, et al. (2006) Shedding of procoagulant microparticles from unstimulated platelets by integrin-mediated destabilization of actin cytoskeleton. FEBS Lett 580(22): 5313-5320.

37. Nomura S, Komiyama Y, Miyake T, Miyazaki Y, Kido, et al. (1994) Amyloidprotein precursor-rich platelet microparticles in thrombotic disease. Thromb Haemost 72(4): 519-522.

38. Furie B, Furie BC (2004) Role of platelet P-selectin and microparticle PSGL-1 in thrombus formation. Trends Mol Med 10(4): 171-178.

39. Barry OP, Practico D, Lawson JA, FitzGerald GA (1997) Transcellular activation of platelets and endothelial cells by bioactive lipids in platelet microparticles. J Clin Invest 99(9): 2118-2127.

40. Garcia B, Smalley DM, Cho H, Shabanowitz J, Ley K, et al. (2005) The platelet particle proteome. J Proteome Res 4(5): 1516-1521.

41. Sprague DL, Elzey BD, Crist SA, Waldschmidt TJ, Jensen RJ, et al. (2008) Platelet-mediated modulation of adaptive immunity: unique delivery of CD154 signal by platelet-derived membrane vesicles. Blood 111(10): 5028-5036.

42. Gilani SI, Weissgerber TL, Garovic VD, Jayachandran M (2016) Preeclampsia and Extracellular Vesicles. Curr Hypertens Rep 18(9): 68.

43. Stepanian A, Bourguignat L, Hennou S, Coupaye M, Hajage D, et al. (2013) Microparticle increase in severe obesity: not related to metabolic syndrome and unchanged after massive weight loss. Obesity (Silver Spring) 21(11): 2236-2243.

44. Preston RA, Jy W, Jimenez JJ, Mauro LM, Horstman LL, et al. (2003) Effects of severe hypertension on endothelial and platelet microparticles. Hypertension 41(2): 211-217.

45. Berezin AE (2016) Prognostication in Different Heart Failure Phenotypes: The Role of Circulating Biomarkers. J Circ Biomark 5: 6 .

46. Berezin AE, Kremzer AA, Martovitskaya YV, Samura TA, Berezina TA (2014) The predictive role of circulating microparticles in patients with chronic heart failure. BBA Clin 3: 18-24.

47. Sabatier F, Darmon P, Hugel B, Combes V, Sanmarco M, et al. (2002) Type 1 and type 2 diabetic patients display different patterns of cellular microparticles. Diabetes 51(9): 2840-2845.

48. Bacha NC, Levy M, Guerin CL, Le Bonniec B, Harroche A, et al. (2019) Treprostinil treatment decreases circulating platelet microvesicles and their procoagulant activity in pediatric pulmonary hypertension. Pediatr Pulmonol 54(1): 66-72.

49. Rosińska J, Łukasik M, Kozubski W (2017) The Impact of Vascular Disease Treatment on Platelet-Derived Microvesicles. Cardiovasc Drugs Ther 31(5-6): 627-644.

50. Berkels R, Egink G, Marsen TA, Bartels H, Roesen R, et al. (2001) Nifedipine increases endothelial nitric oxide bioavailability by antioxidative mechanisms. Hypertension 37(2): 240-245.

51. Santilli F, Marchisio M, Lanuti P, Boccatonda A, Miscia S, et al. (2016) Microparticles as new markers of cardiovascular risk in diabetes and beyond. Thromb Haemost 116(2): 220-234. 


\section{ISSN: 2574-1241}

DOI: 10.26717/BJSTR.2019.17.003072

Alexander E Berezin. Biomed J Sci \& Tech Res

(c) (P) This work is licensed under Creative

Submission Link: https://biomedres.us/submit-manuscript.php

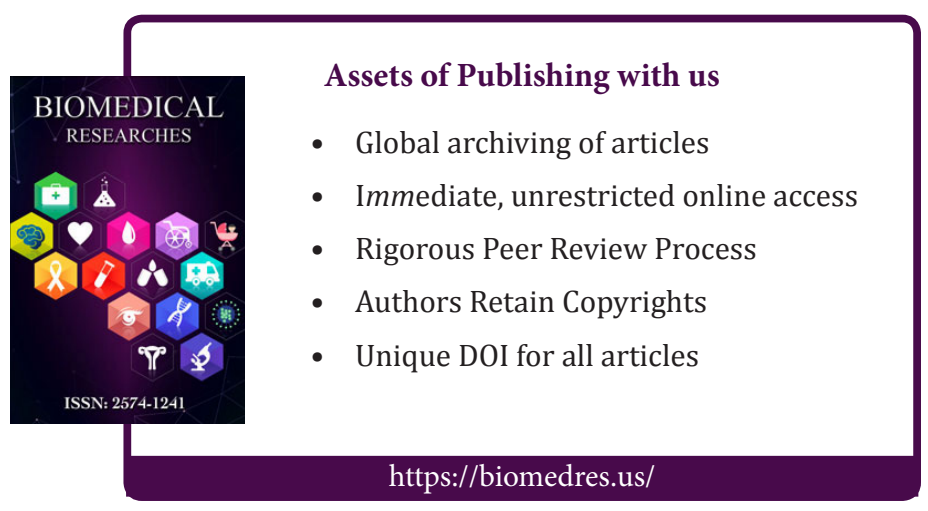

